\title{
The Economic Development of Latin America since Independence
}

\author{
Title: The Economic Development of Latin America since Independence \\ Authors: Bértola, Luis and Ocampo, José Antonio \\ Edition: Oxford University Press, Oxford, 2012, 352 pp. \\ ISBN. 9780199662135 \\ Leonardo WELLER \\ EESP - São Paulo School of Economics -FGV
}

Bértola and Ocampo have written a concise yet informative book on the long-term development of Latin America. With 64 tables and 29 figures, it reviews a wide range of sources and data to assess the reasons why the continent is not part of the developed world. Rather than lagging behind in the long run, the authors argue that the continent went through a "truncated convergence," as periods of intense development alternated with others of crisis and stagnation. They investigate the drivers of this nuanced process and reject the widespread claim that Latin America is cursed to remain underdeveloped.

The book follows the standard division of independent Latin America's history into four periods: the half century after independence, during which states were weak and the economy lagged behind; the half century that preceded the Great Depression, when trade, capital inflow, and immigration boomed; the period between 1930 and 1980, when population grew rapidly and the state promoted industrialization; and the relatively recessive phase that followed thereafter, which combined democracy with economic liberalism. The authors also divide the region geographically in a well-established way: the mountainous countries with large indigenous communities, such as Mexico and Peru; the tropical lowlands that received African slaves, such as Cuba and the Brazilian coast; and the Southern Cone, where European settlers cultivated temperate crops. The authors show that the countries became more similar after the 1930s. Brazil and Mexico grew thanks to their large domestic market and started to catch up with the relatively rich Southern Cone. Matters changed again after the 1980s. Industrial exporting sectors appeared in Mexico and parts of Central America, while South America returned to its commodity-exporting vocation.

This is a notable book in spite of its well-known framework for interpreting Latin America's history and geography. It revisits the main ideas of the Economic Commission for Latin America and the Caribbean (ECLAC) School and downplays the institutional causes of poverty proposed by the highly influential New Institutionalist Economics (NIE). The main message is that world markets prevented the continent from catching-up -a conclusion that cepalinos such as Prebisch, Faletto and Furtado reached in the post-war era. Such an approach does not mean, however, that the book is outdated. On the contrary, it uses new research to contradict some of the NIE's propositions. The authors show that Latin America grew more than new institutionalists had assumed in the aftermath of Independence. The myth of laissez faire during the first globalization (1870s-1930) is debunked. Trade policy promoted industrialization, which contributed to that period's economic growth. They also criticize the belief that Latin America is the world's inequality champion today because of its colonial past -a claim that is often described as the leyenda negra. New long-term series show that inequality boomed during the first globalization and the lost decade of the 1980s. On the other hand, Bértola and Ocampo combine arguments from the ECLAC School with economic orthodoxy. They praise the consensus on sound fiscal accounts and price stability that emerged in the continent during the 1990s.

Nonetheless, the authors go too far in the chapter on industrialization. In an effort to defend the policies implemented between the 1930s and 1970s, they conclude that the debt crisis of the 1980s was the result of an external shock rather than the collapse of the continent's industrialization model. Such an interpretation implies that the model did not entail a severe balance-of- 
payments imbalance. Perhaps this is why they adopt the term "state-led" rather than "import substitution" or "inward-looking" industrialization. Strangely enough, Bértola and Ocampo present facts that point in other directions. They show that import coefficients fell and that states were less interventionist in Latin America than in Africa and Asia, not to mention the Soviet block. The text quotes contemporary cepalinos who criticized the emphasis on domesticallydriven industries and argued that governments should have promoted exports. The Asian tigers did so and performed well in spite of the world crises of the late 1970s. In Latin America, policies were indeed "inward looking," which made the continent vulnerable to external shocks. Industrialization was what it was rather than what the ECLAC wanted it to be.

The chapter on industrialization discards another widely accepted cause of the debt crisis: unsound fiscal policy and inflation. Bértola and Ocampo claim that high inflation was endemic "only" in the Southern Cone and Brazil. This is problematic because that region includes almost all the countries that invested in capital goods and heavy industry. Mexico was the exception in combining industrialization and price stability. Inflation was a major driver of social conflicts in South America, to which populist and military governments provided a number of different answers. The book barely addresses the causes and consequences of populism and dictatorships even though these regimes have deeply marked the continent.

However, the authors do acknowledge that industrial policies had flaws. They argue that poor results in innovation and education prevented Latin America from carrying on growing. Matters could have been different if industrialists were politically stronger than the traditional rural elites. The problem was not the industry but the primary sector. Brazil was the only country that had a relatively strong industrial class, and it went deeper in the industrialization process. But if the relative power of industrial elites was so crucial, why did Brazil also get stuck in the middle income trap, together with the rest of the continent? Perhaps the lack of competition prevented innovation from flourishing and structural inequality deprived people from accessing good education. These are new-institutionalist arguments that Bértola and Ocampo fail to refute. Nevertheless, such limitations do not compromise the book's merit in confronting NIE's monolithic views on Latin America with old ideas and new research. 